\title{
On Approach of Interpretation with Explanations in C-E International Communication of China's Universities
}

\author{
Dan Jiao \\ Henan University of Technology, 450001, Zhengzhou, China \\ Email:danjiao@gmail.com
}

\begin{abstract}
In accordance with the classifications and features summarized with regard to the practical use of international communication of China's universities, through the thinking and practicing in the international affairs work in China's universities, this paper intends to study some interpretation approaches to look for a most effective approach for the guidance of interpreters in practical international communication interpretation work. Among all those interpreting approaches the explanatory interpretation approach is a most effective and commonly used one in the international communication of China's universities.
\end{abstract}

Index Terms - interpretation, explanation, international communication

\section{TRANSLATION APPROACHES AND INTERPRETATION WITH EXPLANATIONS APPROACHES}

From more than two thousand years, the most common terms associated with translation, have been meaning, equivalence, accuracy, technique, and so on. These concepts are purely technical and evaluative, referring to an activity performed on words, sentences and whole texts. Translation has traditionally been thought of in highly mechanical ways: as an impersonal process of transferring a meaning from a source text to a target text without changing it significantly. Interpreters, the people of primary importance behind this process, have been studied largely "in negative ways, in terms of the distortive or disruptive impact of their 'opinions', 'biases', or 'misunderstandings' on the successful completion of the processes". (Robinson, 1997, p.8) To a great extent, theoretical attention to interpreters has been directed at stripping the ideal interpreter of such distortions. It specifically aimed at warning interpreters against errors of all sorts, and intentional or unintentional divergences from the stable meaning of the original text. Therefore, the interpreting activity would not be interfered with human interaction and motivation of the real world.

Newmark (2001) once said "The final solution is explanation when there encounters the situation of at one's wits' end." As a matter of fact, interpretation with explanations accounts for a large proportion during the interpretation process. The commonality of human beings has caused a variety of language semantics that can be accommodated and are understandable within different cultures; therefore it is not that difficult to solve the difference of language forms in the process of interpretation. The interpreter may describe or explain with the most similar source language after totally understanding the original meaning of the message according to his mastered vocabulary and language features of the source language. Only in this way, can they abandon the binding of the specificity of the original grammar and vocabulary to not only make the interpretation language pure mother language but also express the content and style of the original works faithfully. And this kind of interpretation is the explanation to the meaning of language and the most appropriate and equivalent meaning of the original text. In a certain sense, interpretation with explanations is to directly integrate knowledge unknown to readers in original text into the interpretation and not relying on explanatory notes, which is so called "hua yin wei xian".

"What translation theory does is," Newmark said, "first, to identify and define a translation Problem (no problem----no translation theory!); second, to indicate all the factors that have to be taken into account in solving the problem; third, to list all the possible translation procedures; finally, to recommend the most suitable translation procedure, plus the appropriate translation." Then he concluded, "Translation theory is pointless and sterile if it does not arise from the Problems of translation practice..." In addition, he said that the various theories in his book "are only generalizations of translation practices."

From the practical perspective, interpretation with explanations approach refers to the addition of words to make the receptors understand the content of the words and avoiding misunderstandings when the passage refers to some aspects of a country's situation.

\section{CHARACTERS FOR INTERPRETATION IN INTERNATIONAL COMMUNICATION OF CHINA's UNIVERSITIES}

Each interpreter, when interpreting, has the duty to do his best to achieve, to the utmost extent, faithfulness, accuracy and adequacy to enable his receptors to acquire the original message. This should be the goal of interpreters all over the globe. The final standards for the assessment of the quality of a translation, said Mr. Tan Zaixi, a well-known scholar 
and translation theorist, are as follows: (1) The interpretation can enable its readers to comprehend, in a correct way, the information contained in the original text, i.e. it is "faithful to the original"; (2) The interpretation is easy to comprehend; (3) The interpretation has an appropriate form or style that appeals to its receptors. In a word, the interpretation must conform to the requirements for an interpreted text. These three standards may be said to be the crystallization of Nida's Principles of "dynamic equivalence", or "functional equivalence".(Tan, 1984, p.126)

What principle should we apply when interpreting in the international communication of China's universities? In accordance with the general characters of international communication in particular, accuracy, politics, politeness and innovation are the most important principles to apply.

\section{A. Accuracy}

Being the first requirement and characteristic of the language used in diplomatic practice, accuracy is so important that any misusage may result in trouble or even disaster for a nation. This is the same with a university. Commenting on the necessity for the accurate use of language in diplomatic situations, on 8th November, 1949, on the establishment meeting of the Ministry of Foreign Affairs, Premier Zhou Enlai once said, "Diplomacy is a more difficult career than others... Any weakness caught in diplomacy will invite a rebuff from the adversary." "Weakness" mentioned by Premier Zhou refers to a mistake or inappropriateness in language. In this sense, accuracy is also required in interpreting one language into another as well as in using a foreign language directly.

\section{The accuracy of phonetics}

First, one of the fundamental differences between human beings and the other animals is that humans have language with which they can communicate and exchange complex ideas. However, the key point of language is phonetics or pronunciation. Throughout the history of English interpretation, there have been lots of examples of success and lessons of failure as well as the jokes and misunderstandings arising from inaccurate pronunciation. The accuracy of phonetics in international communication of China's universities is the basic requirement for successful interpretation.

For example, once when a China's educational delegation conducted the visiting investigations in abroad, one of the interpreters caused a big misunderstanding because of the inaccurate pronunciation. He originally intended to speak to the waitress that, "Give me the keys, please." But because of the inaccurate pronunciation, the long vowel [i:] was pronounced into the short vowel [i]. The original sentence was thus interpreted as "Give me a kiss.". The inaccuracy of one word's pronunciation caused an international misunderstanding which could certainly have been avoided. Eventually, owing to another interpreter's explanation, the misunderstanding didn't cause an adverse consequence. Again, other words such as "six / sex, sheep / ship, soup / soap, menu / manure" etc. are all the words that are easy to be mispronounced. So the interpreters must have an excellent pronunciation basically and must strictly abide by the standards and requirements of English interpretation in international communication.

\section{The accuracy of listening}

Listening is the most important and difficult hurdle in interpretation of international communication affair. It is also a most important indicator to measure the real interpretation's level of interpreters. There exist big differences between oral interpretation and paper translation. Paper interpreters not only have sufficient time to search for appropriate words and sentences and refine the translation contents repeatedly to make the translation work perfect, but also can look up accessible dictionaries or consult other references. The tasks of oral interpreters are quite different from that of paper translators. Because of the time limitation, oral interpreters are not allowed to refer to dictionaries or consult other people, but have to respond promptly and input or output the information at a high speed on the spot. So interpreters must understand the source language completely to achieve the goal of successful input and output to target receptors.

There are some demands in improving the listening ability for interpreters.

First, the key point that affects listening is the language environment. Interpreters working abroad all year long or those interpreters working with foreigners in domestic environment for a long term can improve their listening abilities very quickly and effectively. Conversely, interpreters who work in a poor language environment where there is little chance to go abroad for visiting tasks or very few foreigners come to visit are sure to improve their listening abilities very slowly. So if they don't have a long-term and planned listening training, their listening ability will become lower and lower. As we know that listening is the first threshold of exchanges, so if they can't listen they can't exchange ideas.

Second, interpreters need to be accustomed to different foreigners' accents. English is most widely used in all over the world. Therefore, the English pronunciation and intonation differ from different people in different countries. For example there are British English, American English, Southeast Asia English, Germany English, England English, and so on. Even in the same country, people in different regions have different pronunciation. For example: There are big differences between British English and American English in pronunciation.

The British English pronunciation of the sentence is: "I can not [ka: nt] do it."

The American English pronunciation of the same sentence is: "I can not [k nt] do it."

The interpreters who are unfamiliar with the pronunciation of American English easily get the information of "I can do it." The two different pronunciations are totally opposite and easily lead to misunderstandings for listeners.

\section{The accuracy of knowledge}

The interpreters' range of knowledge is an important factor that has influences on the interpretation career and is critical to the success of an interpretation. Due to the differences among individual foreign dignitaries, social status, education, occupation, hobbies and so on, the interpreters not only need to know the foreigners' background of politics, 
economics, culture but also the foreign policy, geographic location, climate, communist party and government organizations, even heads of state, but also need to understand the folk traditional customs of foreigners.

A professional interpreter has a wide knowledge range and be able to interpret in more than one area of knowledge accurately. Most professional interpreters are called upon to interpret in a variety of fields. It would be hard to find an interpreter who is a scientist, a lawyer, a medical doctor, and an engineer at the same time. In fact, such a person probably does not exist. One does not have to be a lawyer when s/he is interpreting legal documents. Many a professional interpreter has been able to gain enough knowledge and acquire a vocabulary in a variety of technical fields to be able to produce perfectly accurate and well-written interpretations in those fields. One must, however, have a natural curiosity about many different areas of human knowledge and activity, and an interest in increasing one's vocabulary in a variety of related as well as unrelated fields. On the other hand, one must be sensitive to certain basic principles of interlingual communication, and on the basis of these principles, acquire the necessary skill through extensive practice. Quite clearly, a theory of interpretation is not enough. One must put it into practice. Reading a book about sports such as swimming, skiing, or riding a bicycle will not make one really involved in these activities without practice.

\section{The accuracy of the cross-culture}

Nida (1969) says: "It is true that in all translating and interpreting the source language and target languages must be implicitly or explicitly compared, but all such interlingual communication extends far beyond the mechanics of linguistic similarities and contrasts. One of the main reasons for this is that the meaning of verbal symbols on any and every level depends on the culture of the language community. Language is a part of culture, and in fact, it is the most complex set of habits that any culture exhibits. Language reflects the culture, provides access to the culture, and in many respects constitutes a model of the culture." In the process of translation, cultural messages carried by a certain language can be expressed in another language, thus making cross-cultural communication possible. In this process, new concepts, new genres and new devices are introduced into a target culture. The history of translation is, in a way, the history of the shaping power of one culture upon another.

Interpretation is not only a kind of inter-language activity but also a kind of cross-cultural activity. The differences caused from language and culture will inevitably bring difficulties to interpreters in comprehension. But as an international communication interpreter, a person must accurately understand the different culture and interpret the original against the cross-culture background.

In some cross-cultural communications, there are distinctive differences between English and Chinese in the ways of expression. For example, when Chinese people come to meet the overseas guests, they usually say, “您一路辛苦了!” If we interpret literally into "You must be tired after such a long trip." it will obviously displease the western guests, because the westerners will think that he looks very tired and old. The more appropriate translation is "Did you have a nice trip?" Or "Did you enjoy your trip?" Thus, a correct analysis and comprehension of the original language is the basis of interpretation in practical international communication. If we cannot understand correctly, it will be impossible for us to accurately convey the message. Therefore, in the English interpretation of international communication of China's universities, to understand the differences between English and Chinese culture and to interpret with accurate cross-culture knowledge will make the interpretation effective.

\section{B. Political Nature}

With China's development and opening up, China plays an increasingly important role in the world. More people throughout the world want to have a better understanding of China, not only its culture and history, but also its present political and economic development. Political interpretation in China, as a mouthpiece of the Chinese government, is actually an effective means to inform people within and outside China of its prevailing policies as well as its political and economic affairs. Interpretation, as an indispensable way of cultural exchange and communication between different nations, is therefore decisive in regard to whether these messages can successfully get across to the target language receptor. It therefore demands a high degree of political sensitivity from international communication interpreters.

Accordingly, international communication interpretation is of a political nature. The interpretation content should be strictly faithful to the original text. Interpreters need to consider carefully the selection of words and sentences and accurately convey the stance and attitude of original text. In other words, the political interpretation should be unified by words and ideas. To achieve this, interpreters must be familiar with the current policy integrated with the foreign affairs business. As for the important expressions, particularly related to territorial sovereignty and other vital national interests, interpreters must remain sober-minded and keep a sense of political sensibility. Not only should the literal meaning of the words be interpreted, but the profound connotation of the original words should be expressed. This requires interpretation with explanations. As an interpreter in international communication of China's universities, he should undoubtedly encounter the interpretation cases of a political nature. Under such circumstances, he must be sensitive to the politics of the situation and interpret to foreigners accurately.

\section{Politeness}

Interpreters working in the field of international communications in China's universities actually bear the responsibility of the universities' "diplomatic" task. Because of this, interpreters need to master the knowledge and 
skills of diplomacy.

Diplomatic language is a polite and tactful language. In terms of language, there are two factors which affect the degree of Politeness: One is the degree of intimacy between the addresser and the addressee. The more intimate, the less polite. The less intimate, the more polite. Second, the degree of social status and distance separates the addresser from the addressee. Politeness tends to increase when the addressed is senior in status, and the exchange is less intimate. This is true in diplomacy language. When diplomats meet, they are representing their respective countries, and the relations between one another make them polite and less intimate. This feature is shown in many documents(except for memoranda, legal documents, statements and communiqués) and presentations with prevailingly complimentary phrases.

President Nixon gave his toasts at the banquet given by Premier Zhou Enlai, on February21, 1972, in which he did not fail to use many complementary phrases:

Mr. Prime Minister and all of your distinguished guests this evening:

"On behalf of all of your American guests, I wish to thank you for the incomparable hospitality for which the Chinese people are justly famous throughout the world. I particularly want to pay tribute, not only to those who prepared the magnificent dinner, but also to those who have provided those splendid music. Never have I hear American music played better in a foreign land..."

In the international communication of China's universities, for example, when welcoming foreigners at the airport, the interpreter usually presents a bouquet of flowers as a warm gesture of welcome and courtesy. But he should know well about the various taboos in different countries prior to the presentation. According to the traditional customs and etiquette of China, interpreters usually prepare carnations and add some brief explanations to foreign guests at the appropriate time that carnations represent the warm welcome to visitors in China. This kind of explanation is very helpful under such situations.

International communication interpreters in China's universities should strictly abide by the policy and discipline in the manner of courtesy since the higher education of a country is to some extent a representative of the state's dignity and image. The interpreters must preserve the national interests and abide by national policies and must not express personal views arbitrarily trying to achieve a relaxed, polite and unrestrained atmosphere for international communication.

\section{THE TECHNIQUES OF INTERPRETATION WITH EXPLANATIONS IN INTERNATIONAL COMMUNICATION OF CHINA'S} UNIVERSITIES

\section{A. The Explanation of Proper Names}

In international communications of China's universities, there are many peculiar Chinese expressions and designations such as historical or geographical terms, people's names, peculiar Chinese things, traditional customs etc. Chinese receptors can easily understand those expressions. However, it is clear that foreign receptors who have grown up in a different culture and society, will often be quite unable to recognize these names or phrases and to make the necessary connections in order to make sense of the interpretation. If the interpreter takes it for granted that the foreign readers can understand those peculiar terms and interpret them word-by-word without any explanation, the interpreted text might be unintelligible for the foreign receptors. Because rather than be experts who understand China very well, most of the foreign receptors are just common receptors who don't know much about China, not to mention those peculiar Chinese expressions. For example:

(1) 秦始皇: Speaking of Qin Shihuang, the Chinese people will spontaneously think of him as the first emperor. We know that he was a great person who united China. However, the western people don't know about much of Chinese history. So in their understanding, Qin Shihuang is just the name of a historical person and they do not understand his significance. Under such circumstances, an interpretation with explanations is very helpful to understand the important position of him in Chinese history. Interpreters may add some words like "Qin Shihuang, the first emperor of China who united the country in the second century B.C."

(2) 广州: Guangzhou which is the south gate of our country is also called “Yang Cheng(羊城)”and “Hui Cheng(穗 城)". In the early period of Qin Han, Guang Zhou refers to the prosperous metropolitan city. Under such a historical background, we may translate as "Guangzhou, also known as Canton, lies in the southern-most part of China, adjacent to Hong Kong and Macao. The city's long history dates back to more than two thousand years ago when it became a prosperous trading Port." This paragraph of introduction to Guang Zhou is not interpreted strictly by the style and content of original text. The interpreter augmented the translation with cultural details and supplied background knowledge to guarantee the conveying of original text information. For example, we use the "canton" which is familiar to western people to substitute the word "Yang Cheng" and "Hui Cheng"; use the expression of "Hong Kong and Macao" to show the geographical position of Guang Zhou; and "the period of Qin Han" is implied by the meaning of "two thousand years ago" (Wang, Xu, 2007).

Interpreters in international communication of China's universities should not only work as "work converters", but interpret the ideas in an effective interpreting method to make the international communication interpretation accurate and meaningful. 


\section{B. The Explanation of Acronyms}

Each language continuously creates acronyms and short names as a part of the process of language development. Owing to the generalization and summary of Chinese people, there appear many acronyms and short names with rich connotations and a wide range of meanings in the Chinese language. When interpreting these kinds of words, all the omitted contents should be interpreted or the necessary explanatory statements should be added. Otherwise, the target receptors will not understand the connotation of the meaning. For example: When the interpreter in international communication of China's university introduces Zhengzhou University to foreigners, "211project" is a typical acronym with strong Chinese characteristics which reflects the current educational policy being carried out in China. To reach the goal of mutual understanding between target language receptors and source text speakers, interpreters should apply the method of interpretation with explanations to specifically explain the policy background contained in these phrases. With regard to educational policy in China, Zhenghzhou University is a national "211 project" key university inaugurated by the Henan Provincial Government and the State Ministry of Education on July 10 ${ }^{\text {th }}$, 2000. This interpretation is very clear to foreigners as it states not only the national educational policy and measurements but also the national position of Zhengzhou University in China.

\section{The Explanation of Proverbs and Allusion}

In the international communication of China's universities, it is inevitable that Chinese speakers use some proverbs, idioms and allusion with Chinese characteristics to express the original vividly and humorously. But the characteristic proverbs, idioms and allusions of one language are totally strange to the receptors against the background of another language cultures. Widely well-known legends, historical allusions and proverbs can not be understood by western listeners, because they don't know about the structure of Chinese proverbs and idioms and have little knowledge of the source of historical allusions even the great significance of the proverbs in the culture essence of China. In this case, the interpreters should supply the necessary interpretation with explanations to briefly add the knowledge of the cultural background or use equivalent common expressions to substitute the fixed expressions (Wang, $\mathrm{Xu}, 2007$ ).

\section{Chinese proverbs}

三个臭皮匠，顶个诸葛亮。“Three cobblers with their wits combined equal Zhuge Liang the master mind.”This proverb will certainly arouse questions from target receptors if it is interpreted literally. Who is Zhuge Liang? Why is he compared to the three cobblers? With the method of interpretation with explanations, it is obvious necessary to explain the identity of Zhuge Liang and the relationship between Zhuge and the cobblers. This kind of interpretation not only maintains the Chinese characteristic of original text, but also helps the target language receptors imagine the proverb in their culture of "Two heads are better than one."

Again, during the reception by Foreign Affairs Departments of China's universities, after accommodating the foreigners, there will be a formal welcome meeting with the same status leaders from the host universities. During the meeting, in accordance with the Chinese cultural norms and the international customs of courtesy for the conduct of foreign affairs interpretation, the host parties will deliver a warm speech of welcome. Some leaders like to use some Chinese saying such as “有朋自远方来，不亦悦乎！”. The interpreters need to interpret these Chinese proverbs from classical Chinese into a sentence that is easy to understand but not to interpret word by word. So we have to make the general receptor understand and translate this Chinese proverb into "Is it not a pleasure to have friends visit from afar?" Some explanatory interpretations are also needed before or after this interpretation. "There is a very popular Chinese saying to express the host hospitality in classical Chinese. That is..." Then, the foreign guests may better understand the hospitality being offered by the host and feel more comfortable.

\section{Chinese allusions}

Allusions are usually composed of vivid stories, legends or historical anecdotes, which are of a few words but have deep connotations and wide relevance, such as “夸父追日”，“愚公移山”，“拔苗助长”，“三顾茅庐”，“完璧归赵”etc. From different cultural backgrounds, the receptors can hardly understand the deep connotation between the lines or the relevant stories. For example, if we literally interpret “愚公移山” into “The foolish old man who moved the mountains.", it is too cryptic for foreign receptors. Moreover, interpreters should add some brief explanations about unique Chinese customs, catchphrases and allusions. Although the legends and literary allusions from history are known to Chinese people, most foreigners do not understand them. For example: when we say that Chinese people are building their own country like “愚公移山”, if we don’t add the explanations with a few words, “Yu Gong” will be understood literally as the "silly old man."In order to help the receptors understand the further cultural connotation, it should be interpreted as "This Chinese fable praises the old man's firm and unswerving spirit."

\section{The Explanation of Background Meaning}

Duan Liancheng (1988) pointed out in the book "How to Help Foreigners Know China," that we should neither underestimate the intelligence of foreign receptors nor overestimate the foreigners' general level of understanding about China. The actual meaning refers to the necessity of explanation of background meaning in the international communication interpretation.

In May 1986, Beijing International Broadcast Station conducted a survey and reported on the issues that arose from more than a dozen countries in the audience. The survey results revealed the widespread interest of the audience in both 
China and the Chinese people and how little they know about China. Among those more than 200 issues, some included: What is the China's national flag like? What is the China's national anthem? Who is the President of China? How big is China? What is the population of China? Etc. We should not blame the ignorance of foreigners. But let's try to ask how many Chinese people, including the high educated Chinese, can immediately answer the same questions about our neighborhood Japan? Obviously, we need to introduce necessary additional background knowledge of the country's current situation to foreigners for deeper understanding.

As I have mentioned in chapter three of the addition method in interpretation. We usually need to make additional explanations under the following situations. For example: “before liberation (解放前)” and “after liberation (解放后)”. Any Chinese person knows that this refers to before or after the founding of the PRC in 1949. So if we add the specific year 1949, foreigners will easily understand the exact meaning. When we introduce the foundation history of universities during the international communication, we are better to use the specific year and explain the background specifically. For example, when we make a brief introduction to a university in the welcome meeting, we may introduce with the exact year like this: Henan University of Technology was founded in 1956. Approved by the State Ministry of Education and Henan Provincial Government in May 2004, it was established by the amalgamation of Zhengzhou Institute of Technology and Zhengzhou Polytechnic Institute.

Similarly, even the Chinese primary school students know about the "May 4 Movement (五四运动)" and the “Revolution of 1911 (辛亥革命)", but the foreigners generally do not know. Therefore, we need to make a further explanatory explanation to those foreigners. Often we need to add some more explanation for example "The May 4 Movement in 1919 against foreign imperialism and domestic feudalism "and "The Revolution of 1911 that overthrew the last dynasty and established the country as a Republic". When speaking of the Great Wall and the terracotta warriors, we will naturally mention the Qin Dynasty. But the foreigners cannot recall that "Qin" is the first feudal dynasty in China that arose more than 2,200 years ago. When talking about the Summer Palace and the Palace Museum in Beijing, we will naturally mention the Qing Dynasty. According to the Chinese Phonetic Alphabet, there is only one slight difference of a letter between "Qin" and "Qing". It is very difficult for foreigners to identify these two words. Therefore, if we add the explanation of the years after "Qin" and "Qing" it will be much clearer (Duan,1988).

\section{E. The Explanation of Rhetoric Meaning}

If we sing high praises of a foreign colleague and say that he has a kind of Bethune spirit, we should also have to add a brief note of the moving story of Bethune when he was in China, because very few foreigners have read the book “Selected Works of Mao Zedong” as most Chinese people have. The saying “不到长城非好汉 (Not stop until one reaches the Great Wall.)" has become a most popular mantra among foreign tourists in Beijing, but few people know that this sentence comes from Mao Zedong's poem “Liupanshan(六盘山)”. If the interpreters may give the foreign guests a brief introduction about the poem, it is even more meaningful (Duan,1988). It is the same case with foreign tourist reception. For example, when we visit Sichuan Leshan Giant Buddha, “大肚能容容天下难容之事, 慈言常笑笑 世上可笑之人” is the well-known couplet. When the interpreters introduce the Giant Buddha to foreign guests, some explanatory interpretation need to be added about some of the content of the couplet and knowledge of its history, as well as the Buddhist attitude: Then we interpret it as: "A large heart is tolerant, it tolerates what usually can not be tolerated. A kindly face lights up with smiles, it smiles at those who are smiled." This will give the listeners a profound understanding of the sentence, but also the understanding of the Chinese traditional culture of the couplet.

In most cases, interpreters with a strong sense of responsibility and rich experience can add some necessary explanations into the interpretation to help foreigners understand. But fundamentally speaking, the explanation work is at first the speaker's responsibility; the translation can only do some technical supplementary explanation. What needs explaining will vary from situation to situation depending on the subject, and there is not a definite rule.

\section{F. The Explanation of Figures}

It is very common that large numbers are cited in statistics that are used in Chinese international communication. When we introduce some specific situations to foreigners, we generally present lots of cited statistics, such as the number of billion Jin of food production increase, or the number of hectares of school area. In this kind of introductory meetings, we often see the visitors' facial expressions show that they are at a loss, even if they are interested in the figures. Jin, mu, the Chinese Yuan and other units of measurement are strange to foreigners and have little significance to them. It is easy to make mistakes in interpretation of those numbers, so if some of the major figures can be issued in written materials and distributed to the units of measurement of the metric system and the imperial system, it would be much more effective and more accurate.

Another noteworthy aspect in the phenomenon of the chaos that the use of numbers can engender is that Chinese figures are commonly used in rhetoric rather than a strictly accurate manner. For example, Gezhouba is considered "The first dam of the Yangtze River" (万里长江第一坝) in China with rhetorical numbers. But it could be interpreted into the "The 5,000 kilometers Yangtze River is the first dam" by the interpreter's lack of experience. As we all know, the Yangtze is actually 6,300 kilometers long. The actual length of Great Wall is 13,400 li (6,700 km). Another cause of "numbers confusion" is to excessively use approximate figures, such as "dozen", "nearly 20", "over 30", "about 40" 
"The school has dozens of teachers, hundreds of students," and so on, which gives a blurred view, or may even give the foreigners an erroneous impression.

\section{G. The Explanation of Culture}

Language is the carrier of culture. The cultural customs also need to be transferred to foreigners through language. For example, in the interpretation of traditional culture holidays, the greatest traditional holiday in China is "Spring Festival". It can be interpreted with explanations as: Spring festival is a three-day celebration of the traditional Chinese New Year which falls in January or February according to cycles in the Chinese lunar calendar. 炎黄子孙 is interpreted as: The descent of Yan Di and Huang Di means that all the Chinese people are supposed to be descents of Huang Di and Yan Di, two chiefs of famous ancient tribes in the Huanghe River Valley.

China is a country with a long and rich culture of food. In international communication work, it is inevitable that interpretation of the food culture will arise. As a foreign affairs interpreter, it is necessary to master knowledge of the food culture. For instance, there are great differences between Chinese food and Western food in order of the menu and the way food is served. To create a comfortable and courteous atmosphere for both sides, the foreign affairs interpreters need to briefly introduce the traditional Chinese food culture to foreigners.

Many other traditional culture interpretations such as "dog", "dragon" etc. needs to be interpreted with a supplementary explanation of Chinese traditional culture. Language has different modes of expression in different countries and regions. Interpreters need to know more about history, and society background so as to understand the language essence.

\section{H. The Explanation of Special Meaning}

Under some special circumstances, interpreters need to have the ability to respond promptly and to draw on a rich background of knowledge. We need to add supplementary explanation to some things or phenomena of special meanings to help foreigners further know about the current situation of policy, society and culture.

For example, on November 11, 2005, 1000 days before the opening of the Beijing Olympic Games, the mascot of the Beijing Olympic Games "Fuwa" was unveiled to the public. Fuwa is a set of five dolls, namely, Beibei, Jingjing, Huanhuan, Yingying and Nini. The partial tone of the five characters is "Bei Jing Huan Ying Ni." Beibei conveys a blessing, while Jingjing is a lovely panda. As the national treasure of China, the panda is deeply loved by people of all over the world. Huanhuan symbolizes the Olympic flame and is the embodiment of enthusiasm for sport. It spreads the “Faster, Higher, Stronger” Olympic spirit. Yingying is an agile pantholops hodgsoni (藏羚羊). It comes from west China and spreads health and good blessings to the world. Nini is a swallow from the sky. Nini brings spring and happiness to people and sows the blessing of "Good luck to you." The design of the Olympic mascot stresses putting people first and emphasizes the harmonious co-existence between people and nature (天地合一).

\section{CONCLUSION}

At present, China's international communication interpreters have realized the importance of the interpreting method and have done research on this topic, but most of them contribute papers on how to qualitatively improve the interpretation of China's IC from their own experience, instead of from the perspective of translation theories. This thesis makes a tentative study on how to improve the translation of China's IC in China's universities international affairs work by using as guidelines the principles of Newmark's translation theory of communicative translation and some of Nida's translation theory.

As far as the current China's international cooperation and exchanges situation is concerned, competent interpreters are sure to play important roles in the development of China's international affairs. The level of higher education in a country is an important representative of its comprehensive national strength. Accordingly, the urgent need for professional and efficient interpreters with high qualities in universities is being felt in China's international communication, but how to convey the truth of the development and conduct of the country to the world, with which translating method and how to apply it most effectively is a topic worthy of study.

Chinese interpreters should never stop making efforts to improve their skills in translating in China's IC, since they shoulder the important duty to publicize China, to make an objective and comprehensive international image of China, and then to create a good international environment for China's development. Interpretation plays an important and paramount role in foreign affairs. Different languages predispose their speakers to think differently, so different languages reflect different cultures. Accordingly, among the various translating methods, explanatory translation is a required and practical method of transplanting cultures for China's international communication in universities.

In short, the successful interpretation in the foreign affairs of universities is related to the development of universities and even the higher education of China in the world competition. Therefore, through the hard work of the language researchers and the practical interpreters in foreign affairs, they have reached a final agreed conclusion that the applications of explanatory interpretation will definitely promote the quality of foreign affairs in China's universities and the interpreters should apply this theory to the foreign affairs job.

\section{REFERENCES}


[1] Duan, Liancheng. (1988). How to Help Foreigners Know China: Principle and Skills of Communication. Beijing, China Reconstructs Press.

[2] Fu Xinyu. (2005). On the Approach of Explanatory Interpretation and Application. Lanzhou Academic Journal,6, 303-304

[3] Guo Jianzhong. (1994). On the Concept of Equivalence in Western Translation. Chinese Translators Journal.,4, 95.

[4] Newmark, Peter. (2001). Approaches to Translation. Shanghai, Shanghai Foreign Language Education press.

[5] Nida, Eugene A. and Charles Tabe. (1969). The Theory and Practice of Translation. Leiden, Brill.

[6] Robinson, Douglas. (1997).Translation and Empire: Postcolonial Theories Explained. Manchester, St. Jerome.

[7] Tan Zaixi. (1999). The Theory and Practice of Translation (New Edited). Beijing, China Translation Press

[8] Tan Zaixi. (1984). The Theory and Practice of Translation. Beijing, China Translation Press

[9] Wang Jufang; Xu Hongfang. (2007).Explanatory Translation in the C-E Translation. Journal of Binzhou University. 4,42-45.

[10] Xu Yanan; Li Jianying. (1998). Foreign Affairs Translation. Beijing, World Knowledge Press.

Dan Jiao was born in Inner Mongolia, China in 1979. She received her M.A. degree in English Linguistics from Zhengzhou University, China in 2007.

She is currently a lecturer in the School of Foreign Languages, Henan University of Technology, Zhengzhou, China, and is the section-in-chief in the International Exchange and Cooperation Department of Henan University of Technology. Her research interests include applied translation and interpretation.

Ms. Jiao is a member of Henan Translator's Association, China and the invited expert of English Weekly, China. 